\title{
Anthraquinone derivatives as an immune booster and their therapeutic option against COVID-19
}

\section{Pukar Khanal ( $\nabla$ pukarkhanal58@gmail.com )}

Department of Pharmacology and Toxicology, KLE College of Pharmacy, Belagavi, KLE Academy of Higher Educationa and Research (KAHER), Belagavi-590010, India https://orcid.org/0000-0002-8187-2120

BM Patil ( $\sim$ bmpatil59@hotmail.com )

Department of Pharmacology and Toxicology, KLE College of Pharmacy, Belagavi, KLE Academy of Higher Educationa and Research (KAHER), Belagavi-590010, India

\section{Jagdish chand}

Department of pharmaceutical chemistry, KLE College of Pharmacy, Belagavi, KLE Academy of Higher Educationa and Research (KAHER), Belagavi-590010, India

\section{Yasmin Naaz}

Department of pharmaceutical chemistry, KLE College of Pharmacy, Belagavi, KLE Academy of Higher Educationa and Research (KAHER), Belagavi-590010, India

\section{Research Article}

Keywords: 3clpro, Anthroquine derivatives, COVID-19, Immune boost

Posted Date: June 30th, 2020

DOI: https://doi.org/10.21203/rs.3.rs-39093/v1

License: (c) (i) This work is licensed under a Creative Commons Attribution 4.0 International License. Read Full License

Version of Record: A version of this preprint was published on August 8th, 2020. See the published version at https://doi.org/10.1007/s13659-020-00260-2. 


\section{Abstract}

Multiple Anthraquinolines derivatives are reported for their immune-boosting, anti-inflammatory and anti-viral efficacy. Hence, the present study dealt to investigate the reported anthraquinone derivatives as an immune booster molecule in COVID-19 infection and evaluate their binding affinity with three reported targets of novel coronavirus i.e. 3CLpro, PLpro and spike proteins. The reported anthraquinone derivatives were retrieved from an open-source database and filtered based on a positive druglikeness score. Further, the probably modulated gene by compounds with positive druglikeness score was evaluated for the modulation of proteins using DIGEP-Pred and the interaction of proteins was evaluated using STRING; associated pathways were recorded concerning the KEGG pathway database. Finally, docking was carried using autodock4; pose scoring minimum binding energy was chosen to visualize the ligandprotein interaction. Among 101 compounds, 36 scored positive druglikeness scores; modulating multiple pathways for immune-boosting as well as pathways involved in infectious and non-infectious diseases. Similarly, docking study revealed torososide $B$ to have the highest binding affinity with PLpro and 3clpro and 1,3,6-trihydroxy-2-methyl-9,10anthraquinone-3-0-(6'-0-acetyl)- $\beta$-D-xylopyranosyl-(1->2)- $\beta$-D-glucopyranoside with spike protein

\section{Introduction}

Coronaviruses are the group of an RNA virus and cause diseases to mammals and birds; presently, CoV Disease (COVID-19) has to lead to millions of death in the last six months [1]. Further, the risk of getting affected with COVID-19 is more in subjects with lower immunity. Hence, the special subjects like pediatrics/geriatrics and the subjects suffering from multiple communicable and non-communicable diseases are more risk of getting affected with this virus due to lower immunity [2]. Although approaches are being made to prevent this virus to get spread via social distancing and so on; boosting of immunity in subjects could play an important role in inhibiting the transmission of the virus and its invasion into the body. Investigations are undergoing to develop the vaccine against COVID-19, but it may still take time as the drug discovery process is much complicated. Hence, it is important to identify any alternative approach as prophylaxis against COVID-19 which can be implemented via the utilization of immune boosters from natural sources. Three targets 3C-like protease (3CLpro), papain-like protease (PLpro), and spike protein [3-6] are being targeted by multiple investigators to identify the new hit molecule for the management of COVID-19. Further, in COVID-19 infection severe inflammation and cell necrosis are contributing to the worsening of pathogenesis. Hence, it may be beneficial if a new drug molecule is identified as anti-viral with anti-inflammatory and immune-boosting properties.

Anthroquinolines are the group of compounds from multiple folk medicines like Senna species which are utilized in Ayurvedic system of medicines and Traditional Chinese Medicines for the management of various infectious and non-infectious diseases $[7,8]$. Further, multiple anthraquinone derivatives are also reported as the anti-viral potency [9], anti-inflammatory [10] and also act as immune booster [11]. Since, in the COVID-19 infection, it may be beneficial if the bioactive is identified that acts as the immune booster, anti-inflammatory, and as well as act as anti-viral property which can be demonstrated via the concept of network pharmacology or polypharmacological approach.

Hence, based on the above theme, of anti-viral/anti-inflammatory/immune boosting reports of anthraquinones we attempted to screen the multiple anthraquinone derivatives as an immune booster and anti-viral efficacy using in silico and system biology tools.

\section{Materials And Methods}

\subsection{Bioactives and their druglikeness score}


The reported phytoconstituents under the phytochemistry of anthraquinone were retrieved from available literature/ChEBI records (https://www.ebi.ac.uk/chebi/). All the compounds were then subjected to a druglikeness score by querying the SMILES of each molecule in MolSoft (https://molsoft.com/mprop/).

\subsection{Target prediction and their enrichment analysis}

Anthraquinone derivatives with positive druglikeness scores were then queried in DIGEP-Pred [12] to query "Proteins based targets"; up-regulated/downregulated protein at the probable activity of 0.5 . The list of regulated proteins was then queried in STRING [13] to identify the biological process, cellular function, and molecular processes of combined gene-set. Further, the probably modulated pathways were also identified concerning the KEGG pathway database. Network among the bioactives, their targets, and probably modulated targets were constructed using the Cytoscape [14] version 3.5.1. Any duplicates during the interconnection of two nodes were eliminated to avoid the appearance of a false hit. The whole network was then and analyzed using the "network analyzer" tool based on node size and count representing the edge count as "low values to small size" and "low values to bright colors" respectively as explained previously [16].

\subsection{Prediction of probable anti-viral activity}

Anti-viral activity of each ligand molecule was predicted by querying the SMILES in PASS [17] at Probable activity $(\mathrm{Pa})>$ probable inactivity $(\mathrm{Pi})$; queried keyword "anti-viral" as its probable biological spectrum. Records were queried for their probable pharmacological spectrum against multiple viruses like Adenovirus, CMV, Hepatitis B, Hepatitis $C$, Hepatitis, Herpes, HIV, Influenza A, Influenza, Parainfluenza, Picornavirus, Poxvirus, Rhinovirus, and Trachoma.

\subsection{In silico molecular docking}

\subsubsection{Preparation of ligand molecules}

All the 3D.sdf format of ligand molecules with positive drug-likeness scores was retrieved from PubChem database or structures were drawn in ChemSketch (https://www.acdlabs.com/resources/freeware/chemsketch/) if not available. The ligand molecules were then converted into.pdb format using Discovery studio 2019 [18]. All the bioactives were then minimized using MMFF94 forcefield [19] using conjugate gradients as an optimization algorithm. After the minimization of energy, all ligand molecules were converted into.pdbqt format.

\subsubsection{Preparation of macromolecules}

Three target proteins of COVID-19 i.e. coronavirus main proteinase (3clpro); PDB: 6LU7, papain-like protease (PLpro); PDB: 4MOW and spike proteins (homology modeled target, accession number: AVP78042.1 as query sequence and PDB: 6VSB as a template using SWISS-MODEL [20] were selected. The retrieved proteins were in complex with other heteroatoms which were removed using Discovery studio 2019 and saved in.pdb format.

\subsubsection{Ligand-protein docking}


The ligand molecules were docked with protein molecules using autodock4 [21] by setting 8 exhaustiveness as default to obtain 10 different poses of ligand molecules. After docking the pose scoring lowest binding energy with the target was selected to visualize the ligand-protein interaction in Discovery Studio 2019 as explained previously [22,23].

\section{Results}

\subsection{Bioactives and their druglikeness score}

The complete datasheet of 101 compounds including their name, ChEBI ID, Molecular formula/weight, and synonym including phytochemistry for the retrieved compounds was summarized; Table S1. Among 101 different bioactives; 36 bioactives were identified with positive druglikeness scores. Among them laccaic acid A scored highest druglikeness score i.e. 0.85 with molecular weight 537.09, 12 hydrogen bond acceptor, 8 hydrogen bond donors and 2.88 MolLogP. The details of the druglikeness score of each compound are summarized in Table 1.

\subsection{Target prediction and enrichment analysis}

Among the compounds with positive druglikeness score, anthragallol was predicted to modulate the highest number of genes i.e. 25. Similarly, human carbonyl reductase 1 (CBR1) was targeted by the highest number of bioactives i.e. 33. Similarly, the enrichment analysis identified the modulation of 54 different pathways in which pathways in cancer was majorly modulated by regulating 12 genes (AR, CASP8, CDK4, CTNNB1, EPAS1, HMOX1, KLK3, MMP2, NFE2L2, NOS2, RAC1, RARA) under the background of 515 proteins at the false discovery rate of 7.71E-08. Table 2 summarizes the gene enrichment analysis of the modulated gene set along with modulated pathways with their respective gene codes. The protein-protein interaction of modulated proteins is presented in Figure 1. Similarly, the combined bioactives-proteins-pathways also reflected the anthrogallol to target the highest number of proteins. Likewise, TNFRSF1A was majorly targeted by the highest number of bioactives modulating the pathways in the cancer pathway (Figure 2).

\subsection{Prediction of probable anti-viral activity}

The anthraquinones were found to be anti-viral agents against Adenovirus, CMV, Hepatitis B, Hepatitis C, Hepatitis, Herpes, HIV, Influenza A, Influenza, Parainfluenza, Picornavirus, Poxvirus, Rhinovirus, and Trachoma. Among them, the majority of the compounds were active against herpes virus i.e. $13.28 \%$. The overall activity of compounds against multiple viruses is summarized in Figure 3.

\subsection{In silico molecular docking}

Torososide B was predicted to have the highest binding affinity $(-8.7 \mathrm{kcal} / \mathrm{mol})$ with Papain-Like Protease with 9 hydrogen bond interactions with THR302, ASP303, TYR274, TYR265, ARG167, TYR269, ASP165. Further, Torososide $B$ was predicted to possess the highest binding affinity $(-9.3 \mathrm{kcal} / \mathrm{mol})$ with Coronavirus Main Proteinase with 14 hydrogen bond interaction with LEU287, TYR237, THR199, ARG131, LYS137, LYS5, GLU290, ILE281, LEU282, PHE3. Similarly, 1,3,6-trihydroxy-2-methyl-9,10-anthraquinone-3-0-(6'-0-acetyl)- $\beta$-D-xylopyranosyl-(1->2)- $\beta$-Dglucopyranoside was predicted to possess the highest binding affinity $(-8.7 \mathrm{kcal} / \mathrm{mol})$ with spike protein with the highest number of hydrogen bond interactions i.e. 6 with ASP820, ILE816, ASP815, GLN825, MET703. The binding 
affinity of each compound with individual targets with hydrogen bond interactions and residues is summarized in Table S2. The interaction of Torososide B with Papain-Like Protease and Coronavirus Main Proteinase and 1,3,6trihydroxy-2-methyl-9,10-anthraquinone-3-0-(6'-0-acetyl)- $\beta$-D-xylopyranosyl-(1->2)- $\beta$-D-glucopyranoside with spike protein is presented in Figure 4.

\section{Discussion}

During the COVID-19 infection, several necrosis and inflammation are leading to defect in the supply of necessary nutrients and oxygen into the cells which are more terrible in the subjects with compromised immunity. Hence, in the present study, we investigated multiple anthraquinone derivatives from various traditional medicines to act against COVID-19 targets i.e. 3CLpro, PLpro, and spike protein, and their combined immune-boosting efficacy. Initially, the majority of the plant-based medicines are utilized via the oral route we calculated their druglikeness score based on the "Lipinksi's Rule of Five" [24] which identified 35 different bioactives with positive druglikeness score and were considered to get absorbed from the oral route. Hence, these thirty-six molecules (Table 1) were considered for further study.

The conventional drug discovery process utilizes the concept of "single drug-single protein-single disease" [25] which may not be applicable in the management of infectious diseases. This is due to the affinity of the pathogens (viruses/bacteria) to affect the homeostatic function of protein molecules. It means multiple proteins from the pathogens are involved to generate this effect. Hence, this can be managed via the utilization of modified drug development process "multi compound-multi protein-disease" interaction in which multiple bioactives regulate multiple proteins [15] which can also be taken as a basic key of boosting the immune system. Hence, in the present study, the combined synergistic phenomena of anthraquinones were investigated rather than a single bioactive molecule that identified the multiple pathways which are directly or indirectly involved in the immune system.

Gene set enrichment analysis identified multiple pathways like p53 signaling pathway [26], PI3K-Akt signaling pathway [27], Rap1 signaling pathway [28], NF-kappa B signaling pathway [29] which are directly involved in the boosting the immune system. Similarly, some other pathways like pathways in cancer, PPAR signaling pathway, colorectal cancer, chemical carcinogenesis, estrogen signaling pathway were also identified which reflects the potency of anthraquinones to be beneficial in the subjects which are suffering from these pathways associated diseases like cancer. Further, pathways like p53 signaling pathways, PI3K-AKT, Wnt signaling pathways are also associated diseases like compromised immune systems like diabetes and obesity; which could be beneficial in managing the diseases they are suffering and boosting the immune system. Additionally, the enrichment analysis identified the modulation of multiple pathways that are associated with a pathogenic infection like viral myocarditis and tuberculosis; reflects the potency to manage the infectious diseases. Further, previous reports also reflect the antiviral potency of the multiple plants that are rich in anthraquinones against various viruses. Hence, we attempted to identify the probable anti-viral activity of the anthraquinones with positive druglikeness score which identified their efficacy against multiple viruses like the rhino, influenza, herpes trachoma, pox, and CMV.

3C-like protease or main protease of coronavirus (3CLpro) alters the ubiquitin system to incorporate the viral polypeptides; deregulates the homeostatic task of functional proteins [30]; which was majorly targeted by Torososide B. Further, PLpro alters the function of protein phosphatase 1A (pp1a) and protein phosphatase 1B (pp1b) into the replicase proteins to adjust viral life cycle [31];majorly inhibited by Torososide B. Similarly, spike protein utilizes angiotensin-converting enzyme 2 (ACE-2) as a receptor to enter inside the host cell $[32,33]$ which was chiefly regulated by modulated by 1,3,6-trihydroxy-2-methyl-9,10-anthraquinone-3-0-(6'-0-acetyl)- $\beta$-D-xylopyranosyl-(1->2)$\beta$-D-glucopyranoside. These results reflect the potency of the anthraquinone derivatives to act as the anti-viral 
potency against COVID-19. However, as the time proceeds, it is to be understood that the binding affinity of probable lead hit molecules may get altered due to mutation in the possible protein targets and the inhibitory function may not occur as predicted.

\section{Conclusion}

The present study utilized in silico molecular docking tools to identify the binding affinity of previously recorded anthraquinones derivatives against 3clpro, PLpro, and spike protein which identified Torososide B and 1,3,6trihydroxy-2-methyl-9,10-anthraquinone-3-0-(6'-0-acetyl)- $\beta$-D-xylopyranosyl-(1->2)- $\beta$-D-glucopyranoside as a lead hits. Similarly, the combined synergies of the network identified the modulation of multiple pathways involved in the immune system like p53, chemokine, and PI3K-Akt signaling pathways. Additionally, anthraquinone derivatives were also identified as the modulators of the disease pathways where the immune system is compromised like diabetes and obesity. All these results suggest the probable therapeutic option od utilization of anthraquinones as an immune booster and anti-viral against novel coronavirus by acting on the three targets as investigated. However, the present findings are only based on the computer simulations which need to be further validated using well designed experimental protocols.

\section{Declarations}

\section{Acknowledgements}

All the authors are thankful to Principal KLE College of Pharmacy, Belagavi, KAHER Belagavi for his support for this completion of this work.

\section{Authors' contribution}

Pukar Khanal developed the protocol and performed the work and drafted the manuscript. Prof. B.M. Patil revied and finalized the manuscript draft. Jagdish chand and Yasmin Naaz had equal contribution in mining the database and assisting in the work performance.

\section{Funding}

Not available

\section{Conflict of interest}

There is no conflict of interest.

\section{Ethical statement}

This manuscript doesn't include any animal or human studies

\section{References}

1. A. Miura, K.V. Holmes. J Leukoc Biol. 86, 1145-51 (2009).

2. Science News. [Internet] https://www.sciencedaily.com/releases/2020/03/200317103815.htm. Accessed on: 2805-2020 
3. Khanal, T. Duyu, B.M. Patil, Y.N. Dey, I. Pasha, R.S. Kavalapure. Research Square. Doi: 10.21203/rs.3.rs-32233/v1 (2020a)

4. Khanal, T. Duyu, Y.N. Dey, I. Pasha, M. Wanjari. Research Square doi: 10.21203/rs.3.rs-31776/v1 (2020b)

5. H. Zhang, K.L. Wu, X. Zhang, S.Q. Deng, B. Peng. J Integr Med 18, 152-158 (2020).

6. Mahdian, A. Ebrahim-Habibi, M. Zarrabi, J Diabetes Metab Disord. https://doi.org/10.1007/s40200-020-00546-9 (2020)

7. E. M. Malik, C. E. Müller, Medicinal research reviews. 36, 705-748 (2016). https://doi.org/10.1002/med.21391

8. S. C. Chien, Y. C. Wu, Z. W. Chen, W. C. Yang, Evidence-based complementary and alternative medicine : eCAM, 2015, 357357 (2015).

9. D. O. Andersen, N. D. Weber, S. G. Wood, B. G. Hughes, B. K. Murray, J. A. North, Antiviral research, 16, 185-196 (1991).

10. A. D. Kshirsagar, P. V. Panchal, U. N. Harle, R. K. Nanda, H. M. Shaikh, International journal of inflammation, 2014, 690596 (2014).

11. G. K. Panigrahi, A. Yadav, P. Mandal, A. Tripathi, M. Das, Toxicology letters, 245, 15-23 (2016).

12. A. Lagunin, S. Ivanov, A. Rudik, D. Filimonov, V. Poroikov, Bioinformatics. 29,2062-3 (2013).

13. D. Szklarczyk, J.H. Morris, H. Cook, M. Kuhn, S. Wyder, M. Simonovic, et al. Nucleic Acids Res. 45, D362-8 (2017).

14. P. Shannon, A. Markiel, O. Ozier, N.S. Baliga, J.T. Wang, D. Ramage, et al. Genome Res. 13,2498-504 (2003).

15. P. Khanal, B.M. Patil. Journal of Diabetes \& Metabolic Disorders, DOI: https://doi.org/10.1007/s40200-02000554-9 (2020).

16. P. Khanal, B.M. Patil. Advances in Traditional Medicine. DOI: https://doi.org/10.1007/s13596-020-00426-w (2020).

17. V.V. Poroikov, D.A. Filimonov, W.D. Ihlenfeldt, T.A. Gloriozova, A.A. Lagunin, Y.V. Borodina, et al. J Chem Inf Comput Sci 43,228-36 (2003).

18. Dassault Systèmes BIOVIA, Discovery S. 2019, San Diego: DassaultSystèmes, 2019.

19. T.A. Halgren. J Comput Chem.17, 490-519 (1996).

20. T. Schwede, J. Kopp, N. Guex, M. C. Peitsch,. Nucleic acids research 31, 3381-3385 (2003) https://doi.org/10.1093/nar/gkg520

21. G.M. Morris, R. Huey, W. Lindstrom, M.F. Sanner, R.K. Belew, D.S. Goodsell, et al. J Comput Chem. 30, 2785-91 (2009). https://doi.org/10.1002/jcc.21256.

22. P. Khanal, B.M. Patil, K.K. Hullatti, Indian Journal of Pharmaceutical Sciences. 81,550-5 (2019).

23. P. Khanal, P. Magadum, B.M. Patil, K.K. Hullatti, Indian Journal of Pharmaceutical Sciences, 81, 326-32 (2019).

24. C.A. Lipinski, Drug Discov Today Technol 1, 337-41 (2004).

25. P. Khanal, B.M. Patil, Asian Pacific Journal of Tropical Biomedicine. 9, 263 (2019).

26. C. Muñoz-Fontela, A. Mandinova, S.A. Aaronson, S.W. Lee, Nat Rev Immunol. 16,741-750 (2016). doi: 10.1038/nri.2016.99.

27. T. Weichhart, M.D. Säemann, Ann Rheum Dis. 67, iii70-4 (2008).

28. D.S. Johnson, Y.H. Chen, Curr Opin Pharmacol. 12, 458-63 (2012).

29. C.L. Sokol, A.D. Luster, Cold Spring Harb Perspect Biol 7, a016303 (2015).

30. V. G. Bhoj, Z.J. Chen, Nature 458, 430-7 (2009).

31. H.A. Lindner, N. Fotouhi-Ardakani, V. Lytvyn, P. Lachance, T. Sulea, R. Ménard, J Virol 79, 15199-208 (2005). 
32. W. Li, M.J. Moore, N. Vasilieva, J. Sui, S. K. Wong, M.A. Berne, M. Somasundaran, J.L. Sullivan, K. Luzuriaga, T.C. Greenough, H. Choe, M. Farzan, Nature, 426, 450-4 (2003).

33. J.H. Kuhn, W. Li, H. Choe, M. Farzan, Cell Mol Life Sci 61, 2738-43 (2004).

\section{Tables}

Table 1: Druglikeness of anthraquinone derivatives with positive score 


\begin{tabular}{|c|c|c|c|c|c|c|c|c|}
\hline Bioactives & $\begin{array}{l}\text { Molecular } \\
\text { Formula }\end{array}$ & $\begin{array}{l}\text { Molecular } \\
\text { Weight }\end{array}$ & NHBA & NHBD & MolLogP & $\begin{array}{l}\text { MolPSA } \\
\left(A^{2}\right)\end{array}$ & $\begin{array}{l}\text { MolVol } \\
\left(A^{3}\right)\end{array}$ & DLS \\
\hline $\begin{array}{l}\text { versicolorone tricyclic } \\
\text { form }\end{array}$ & $\mathrm{C}_{20} \mathrm{H}_{18} \mathrm{O}_{8}$ & 386.1 & 8 & 5 & 1.67 & 122.82 & 375.84 & 0.09 \\
\hline $\begin{array}{l}(1 \text { 'S, } 5 \text { 'S)-5'- } \\
\text { hydroxyaverantin }\end{array}$ & $\mathrm{C}_{20} \mathrm{H}_{20} \mathrm{O}_{8}$ & 388.12 & 8 & 6 & 1.9 & 125 & 371.14 & 0.17 \\
\hline $\begin{array}{l}\left(1 ' S, 5^{\prime} R\right)-5^{\prime}- \\
\text { hydroxyaverantin }\end{array}$ & $\mathrm{C}_{20} \mathrm{H}_{20} \mathrm{O}_{8}$ & 388.12 & 8 & 6 & 1.9 & 125 & 371.14 & 0.17 \\
\hline $\begin{array}{l}\text { chrysophanol 8-O- } \beta-D- \\
\text { glucoside }\end{array}$ & $\mathrm{C}_{21} \mathrm{H}_{20} \mathrm{O}_{9}$ & 416.11 & 9 & 5 & 1.11 & 122.67 & 379.02 & 0.45 \\
\hline $\begin{array}{l}\text { 1,3,6-trihydroxy-2- } \\
\text { methyl-9,10- } \\
\text { anthraquinone-3-O-(6'- } \\
\text { O-acetyl)-a-L- } \\
\text { rhamnopyranosyl-(1- } \\
\text { >2)-3-D- } \\
\text { glucopyranoside }\end{array}$ & $\mathrm{C}_{29} \mathrm{H}_{32} \mathrm{O}_{15}$ & 620.17 & 15 & 7 & 1.46 & 189.78 & 556.02 & 0.6 \\
\hline 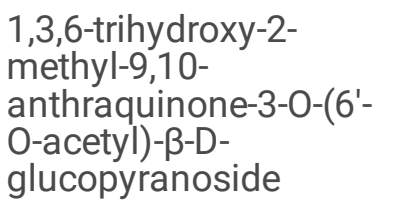 & $\mathrm{C}_{23} \mathrm{H}_{22} \mathrm{O}_{11}$ & 474.12 & 11 & 5 & 2.07 & 143.34 & 436.83 & 0.45 \\
\hline $\begin{array}{l}\text { 1,3,6-trihydroxy-2- } \\
\text { methyl-9,10- } \\
\text { anthraquinone-3-O-a-L- } \\
\text { rhamnopyranosyl-(1- } \\
\text { >2)- } \beta \text {-D- } \\
\text { glucopyranoside }\end{array}$ & $\mathrm{C}_{27} \mathrm{H}_{30} \mathrm{O}_{14}$ & 578.16 & 14 & 8 & 0.85 & 185.66 & 510.27 & 0.5 \\
\hline 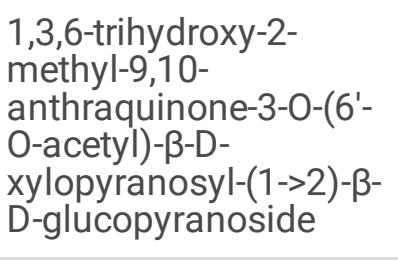 & $\mathrm{C}_{28} \mathrm{H}_{30} \mathrm{O}_{15}$ & 606.16 & 15 & 7 & 1.01 & 190.6 & 540.52 & 0.69 \\
\hline $\begin{array}{l}\text { 1,3,6-trihydroxy-2- } \\
\text { methyl-9,10- } \\
\text { anthraquinone-3-O-(3'- } \\
\text { O-acetyl)-a-L- } \\
\text { rhamnopyranosyl-(1- } \\
\text { >2)-3-D- } \\
\text { glucopyranoside }\end{array}$ & $\mathrm{C}_{29} \mathrm{H}_{32} \mathrm{O}_{15}$ & 620.17 & 15 & 7 & 1.42 & 190.3 & 556.1 & 0.76 \\
\hline $\begin{array}{l}\text { 1-hydroxy-2-( } \beta-D- \\
\text { glucosyloxy)-9,10- } \\
\text { anthraquinone }\end{array}$ & $\mathrm{C}_{20} \mathrm{H}_{18} \mathrm{O}_{9}$ & 402.1 & 9 & 5 & 1.1 & 121.6 & 358.41 & 0.04 \\
\hline (2S)-versicolorone & $\mathrm{C}_{20} \mathrm{H}_{18} \mathrm{O}_{8}$ & 386.1 & 8 & 5 & 1.67 & 122.82 & 375.84 & 0.09 \\
\hline (S)-5'-oxoaverantin & $\mathrm{C}_{20} \mathrm{H}_{18} \mathrm{O}_{8}$ & 386.1 & 8 & 5 & 1.77 & 121.86 & 374.32 & 0.16 \\
\hline BDA-366 & $\mathrm{C}_{24} \mathrm{H}_{29} \mathrm{~N}_{3} \mathrm{O}_{4}$ & 423.22 & 5 & 3 & 2.54 & 74.7 & 440.1 & 0.09 \\
\hline Emodin 8-glucoside & $\mathrm{C}_{21} \mathrm{H}_{20} \mathrm{O}_{10}$ & 432.11 & 10 & 6 & 0.61 & 140.29 & 389.71 & 0.74 \\
\hline anthragallol & $\mathrm{C}_{21} \mathrm{H}_{20} \mathrm{O}_{10}$ & 432.11 & 10 & 6 & 0.61 & 140.29 & 389.71 & 0.74 \\
\hline
\end{tabular}




\begin{tabular}{|c|c|c|c|c|c|c|c|c|}
\hline nogalonic acid & $\mathrm{C}_{20} \mathrm{H}_{14} \mathrm{O}_{8}$ & 382.07 & 8 & 3 & 2.33 & 113.17 & 370.61 & 0.44 \\
\hline mitoxantrone & $\mathrm{C}_{22} \mathrm{H}_{28} \mathrm{~N}_{4} \mathrm{O}_{6}$ & 444.2 & 8 & 8 & -0.55 & 135.33 & 432.17 & 0.53 \\
\hline torososide B & $\mathrm{C}_{40} \mathrm{H}_{52} \mathrm{O}_{25}$ & 932.28 & 25 & 14 & -4.46 & 320.41 & 789.36 & 0.63 \\
\hline versicolorone & $\mathrm{C}_{20} \mathrm{H}_{16} \mathrm{O}_{7}$ & 368.09 & 7 & 3 & 2.68 & 97.9 & 364.43 & 0.14 \\
\hline $\begin{array}{l}\text { 4'-O- } \\
\text { demethylknipholone-4'- } \\
\text { O- } \beta \text {-D-glucopyranoside }\end{array}$ & $\mathrm{C}_{29} \mathrm{H}_{26} \mathrm{O}_{13}$ & 582.14 & 13 & 8 & 1.91 & 184.8 & 529.73 & 0.61 \\
\hline aklanonic acid & $\mathrm{C}_{21} \mathrm{H}_{16} \mathrm{O}_{8}$ & 396.08 & 8 & 3 & 2.83 & 112.59 & 389.73 & 0.51 \\
\hline kermesic acid & $\mathrm{C}_{16} \mathrm{H}_{10} \mathrm{O}_{8}$ & 330.04 & 8 & 5 & 2.1 & 119.71 & 304.77 & 0.06 \\
\hline gaboroquinone $\mathrm{A}$ & $\mathrm{C}_{24} \mathrm{H}_{18} \mathrm{O}_{9}$ & 450.1 & 9 & 5 & 3.35 & 130.76 & 428.49 & 0.27 \\
\hline variecolorquinone $\mathrm{A}$ & $\mathrm{C}_{20} \mathrm{H}_{18} \mathrm{O}_{9}$ & 402.1 & 9 & 4 & 1.36 & 121.77 & 383.49 & 0.71 \\
\hline laccaic acid $A$ & $\mathrm{C}_{26} \mathrm{H}_{19} \mathrm{NO}_{12}$ & 537.09 & 12 & 8 & 2.88 & 186.68 & 496.66 & 0.85 \\
\hline laccaic acid B & $\mathrm{C}_{24} \mathrm{H}_{16} \mathrm{O}_{12}$ & 496.06 & 12 & 8 & 3.19 & 178.91 & 446.68 & 0.65 \\
\hline laccaic acid C & $\mathrm{C}_{25} \mathrm{H}_{17} \mathrm{NO}_{13}$ & 539.07 & 14 & 10 & 0.68 & 211.46 & 476.5 & 0.68 \\
\hline carminic acid & $\mathrm{C}_{22} \mathrm{H}_{20} \mathrm{O}_{13}$ & 492.09 & 13 & 9 & 0.62 & 189.58 & 434.4 & 0.77 \\
\hline ekatetrone & $\mathrm{C}_{19} \mathrm{H}_{13} \mathrm{NO}_{7}$ & 367.07 & 7 & 4 & 2.12 & 112.76 & 348.31 & 0.5 \\
\hline $\begin{array}{l}\text { 4-bromo-1- } \\
\text { hydroxyanthraquinone- } \\
\text { 2-carboxylic acid }\end{array}$ & $\mathrm{C}_{15} \mathrm{H}_{7} \mathrm{BrO}_{5}$ & 345.95 & 5 & 2 & 4.39 & 70.07 & 269.12 & 0.24 \\
\hline scutianthraquinone $\mathrm{A}$ & $\mathrm{C}_{39} \mathrm{H}_{32} \mathrm{O}_{13}$ & 708.18 & 13 & 4 & 7.75 & 165.64 & 711.03 & 0.45 \\
\hline scutianthraquinone B & $\mathrm{C}_{38} \mathrm{H}_{30} \mathrm{O}_{13}$ & 694.17 & 13 & 4 & 7.41 & 165.64 & 693.71 & 0.26 \\
\hline scutianthraquinone $\mathrm{C}$ & $\mathrm{C}_{34} \mathrm{H}_{24} \mathrm{O}_{12}$ & 624.13 & 12 & 5 & 5.88 & 161.07 & 618.22 & 0.31 \\
\hline $\begin{array}{l}\text { 1,3,6-trihydroxy-2- } \\
\text { hydroxymethyl-9,10- } \\
\text { anthraquinone-3-0-(6'- } \\
\text { O-acetyl)- } \beta-D- \\
\text { glucopyranoside }\end{array}$ & $\mathrm{C}_{23} \mathrm{H}_{22} \mathrm{O}_{12}$ & 490.11 & 12 & 6 & 0.93 & 160.45 & 445.01 & 0.41 \\
\hline rubianthraquinone & $\mathrm{C}_{16} \mathrm{H}_{12} \mathrm{O}_{5}$ & 284.07 & 5 & 2 & 3.26 & 68.06 & 281.86 & 0.07 \\
\hline $\begin{array}{l}\text { 5- } \\
\text { hydroxyanthraquinone- } \\
\text { 1,3-dicarboxylic acid }\end{array}$ & $\mathrm{C}_{16} \mathrm{H}_{8} \mathrm{O}_{7}$ & 312.03 & 7 & 3 & 3.47 & 99.54 & 281.87 & 0.28 \\
\hline
\end{tabular}

DLS: Druglikeness score

Table 2: Enrichment analysis of modulated proteins by the reported anthraquinone derivatives 


\begin{tabular}{|c|c|c|c|c|c|}
\hline \#term ID & term description & $\begin{array}{l}\text { observed } \\
\text { gene } \\
\text { count }\end{array}$ & $\begin{array}{l}\text { background } \\
\text { gene count }\end{array}$ & $\begin{array}{l}\text { false } \\
\text { discovery } \\
\text { rate }\end{array}$ & $\begin{array}{l}\text { matching proteins in your } \\
\text { network (labels) }\end{array}$ \\
\hline hsa05200 & Pathways in cancer & 12 & 515 & 7.71E-08 & $\begin{array}{l}\text { AR, CASP8, CDK4, CTNNB1, } \\
\text { EPAS1, HMOX1, KLK3, MMP2, } \\
\text { NFE2L2, NOS2, RAC1, RARA }\end{array}$ \\
\hline hsa05418 & $\begin{array}{l}\text { Fluid shear stress and } \\
\text { atherosclerosis }\end{array}$ & 7 & 133 & $1.18 \mathrm{E}-06$ & $\begin{array}{l}\text { CTNNB1, HMOX1, MMP2, } \\
\text { NFE2L2,'PLAT, RAC1, } \\
\text { TNFRSF1A }\end{array}$ \\
\hline hsa05167 & $\begin{array}{l}\text { Kaposi's sarcoma- } \\
\text { associated herpesvirus } \\
\text { infection }\end{array}$ & 6 & 183 & 0.00012 & $\begin{array}{l}\text { CASP } 8, \text { CD 86, CDK4, CTNNB1, } \\
\text { RAC1, TNFRSF1A }\end{array}$ \\
\hline hsa05215 & Prostate cancer & 5 & 97 & 0.00012 & AR, CTNNB1, KLK3, PLAT, PLAU \\
\hline hsa05014 & $\begin{array}{l}\text { Amyotrophic lateral } \\
\text { sclerosis (ALS) }\end{array}$ & 4 & 50 & 0.00015 & CAT, GPX1, RAC1, TNFRSF1A \\
\hline hsa04932 & $\begin{array}{l}\text { Non-alcoholic fatty liver } \\
\text { disease (NAFLD) }\end{array}$ & 5 & 149 & 0.00044 & $\begin{array}{l}\text { ADIPOQ, CASP8, PPARA, RAC1, } \\
\text { TNFRSF1A }\end{array}$ \\
\hline hsa05202 & $\begin{array}{l}\text { Transcriptional } \\
\text { misregulation in cancer }\end{array}$ & 5 & 169 & 0.00068 & CD86, FLT1, PLAT, PLAU, RARA \\
\hline hsa04066 & $\begin{array}{l}\text { HIF-1 signaling } \\
\text { pathway }\end{array}$ & 4 & 98 & 0.0012 & FLT1, HMOX1, NOS2, TIMP1 \\
\hline hsa00380 & $\begin{array}{l}\text { Tryptophan } \\
\text { metabolism }\end{array}$ & 3 & 40 & 0.0017 & CAT, CYP1A1, CYP1A2 \\
\hline hsa04915 & $\begin{array}{l}\text { Estrogen signaling } \\
\text { pathway }\end{array}$ & 4 & 133 & 0.003 & FKBP5, MMP2, PGR, RARA \\
\hline hsa05416 & Viral myocarditis & 3 & 56 & 0.0037 & CASP8, CD86, RAC1 \\
\hline hsa00980 & $\begin{array}{l}\text { Metabolism of } \\
\text { xenobiotics by } \\
\text { cytochrome P450 }\end{array}$ & 3 & 70 & 0.0053 & CBR1, CYP1A1, CYP1A2 \\
\hline hsa04115 & p53 signaling pathway & 3 & 68 & 0.0053 & CASP8, CDK4, CHEK1 \\
\hline hsa04920 & $\begin{array}{l}\text { Adipocytokine } \\
\text { signaling pathway }\end{array}$ & 3 & 69 & 0.0053 & ADIPOQ, PPARA, TNFRSF1A \\
\hline hsa05152 & Tuberculosis & 4 & 172 & 0.0053 & CASP8, NOS2, TNFRSF1A, VDR \\
\hline hsa05225 & $\begin{array}{l}\text { Hepatocellular } \\
\text { carcinoma }\end{array}$ & 4 & 163 & 0.0053 & $\begin{array}{l}\text { CDK4, CTNNB1, HMOX1, } \\
\text { NFE2L2 }\end{array}$ \\
\hline hsa05203 & Viral carcinogenesis & 4 & 183 & 0.0056 & CASP8, CDK4, CHEK1, RAC1 \\
\hline hsa05204 & $\begin{array}{l}\text { Chemical } \\
\text { carcinogenesis }\end{array}$ & 3 & 76 & 0.0056 & CBR1, CYP1A1,CYP1A2 \\
\hline hsa05205 & $\begin{array}{l}\text { Proteoglycans in } \\
\text { cancer }\end{array}$ & 4 & 195 & 0.0065 & CTNNB1, MMP2, PLAU, RAC1 \\
\hline hsa04933 & $\begin{array}{l}\text { AGE-RAGE signaling } \\
\text { pathway in diabetic } \\
\text { complications }\end{array}$ & 3 & 98 & 0.0097 & CDK4, MMP2, RAC1 \\
\hline hsa04620 & Toll-like receptor & 3 & 102 & 0.01 & CASP8, CD86, RAC1 \\
\hline
\end{tabular}


signaling pathway

\begin{tabular}{|c|c|c|c|c|c|}
\hline hsa05142 & $\begin{array}{l}\text { Chagas disease } \\
\text { (American } \\
\text { trypanosomiasis) }\end{array}$ & 3 & 101 & 0.01 & CASP8, NOS2, TNFRSF1A \\
\hline hsa05145 & Toxoplasmosis & 3 & 109 & 0.0113 & CASP8, NOS2, TNFRSF1A \\
\hline hsa04670 & $\begin{array}{l}\text { Leukocyte } \\
\text { transendothelial } \\
\text { migration }\end{array}$ & 3 & 112 & 0.0117 & CTNNB1, MMP2, RAC1 \\
\hline hsa05166 & HTLV-I infection & 4 & 250 & 0.0121 & $\begin{array}{l}\text { CDK4, CHEK1, CTNNB1, } \\
\text { TNFRSF1A }\end{array}$ \\
\hline hsa04215 & $\begin{array}{l}\text { Apoptosis - multiple } \\
\text { species }\end{array}$ & 2 & 31 & 0.0131 & CASP8, TNFRSF1A \\
\hline hsa04216 & Ferroptosis & 2 & 40 & 0.0204 & GSS, HMOX1 \\
\hline hsa04310 & Wnt signaling pathway & 3 & 143 & 0.0204 & CTNNB1, MMP7, RAC1 \\
\hline hsa05219 & Bladder cancer & 2 & 41 & 0.0204 & CDK4, MMP2 \\
\hline hsa05224 & Breast cancer & 3 & 147 & 0.0204 & CDK4, CTNNB1, PGR \\
\hline hsa05165 & $\begin{array}{l}\text { Human papillomavirus } \\
\text { infection }\end{array}$ & 4 & 317 & 0.0226 & $\begin{array}{l}\text { CASP8, CDK4, CTNNB1, } \\
\text { TNFRSF1A }\end{array}$ \\
\hline hsa00480 & $\begin{array}{l}\text { Glutathione } \\
\text { metabolism }\end{array}$ & 2 & 50 & 0.0261 & GPX1, GSS \\
\hline hsa04978 & Mineral absorption & 2 & 51 & 0.0263 & HMOX1, VDR \\
\hline hsa04151 & $\begin{array}{l}\text { PI3K-Akt signaling } \\
\text { pathway }\end{array}$ & 4 & 348 & 0.0285 & CDK4, FLT1, GH1, RAC1 \\
\hline hsa00140 & $\begin{array}{l}\text { Steroid hormone } \\
\text { biosynthesis }\end{array}$ & 2 & 58 & 0.0316 & CYP1A1, CYP1A2 \\
\hline hsa00590 & $\begin{array}{l}\text { Arachidonic acid } \\
\text { metabolism }\end{array}$ & 2 & 61 & 0.0337 & CBR1, GPX1 \\
\hline hsa00830 & Retinol metabolism & 2 & 62 & 0.0338 & CYP1A1, CYP1A2 \\
\hline hsa04024 & $\begin{array}{l}\text { cAMP signaling } \\
\text { pathway }\end{array}$ & 3 & 195 & 0.0339 & PPARA, RAC1, TNNI3 \\
\hline hsa04510 & Focal adhesion & 3 & 197 & 0.034 & CTNNB1, FLT1, RAC1 \\
\hline hsa04015 & $\begin{array}{l}\text { Rap1 signaling } \\
\text { pathway }\end{array}$ & 3 & 203 & 0.0359 & CTNNB1, FLT1, RAC1 \\
\hline hsa05211 & Renal cell carcinoma & 2 & 68 & 0.0363 & EPAS1, RAC1 \\
\hline hsa01524 & $\begin{array}{l}\text { Platinum drug } \\
\text { resistance }\end{array}$ & 2 & 70 & 0.0374 & CASP8, TOP2A \\
\hline hsa04520 & Adherens junction & 2 & 71 & 0.0375 & CTNNB1, RAC1 \\
\hline hsa03320 & $\begin{array}{l}\text { PPAR signaling } \\
\text { pathway }\end{array}$ & 2 & 72 & 0.0376 & ADIPOQ, PPARA \\
\hline hsa05100 & $\begin{array}{l}\text { Bacterial invasion of } \\
\text { epithelial cells }\end{array}$ & 2 & 72 & 0.0376 & CTNNB1, RAC1 \\
\hline
\end{tabular}




\begin{tabular}{|c|c|c|c|c|c|}
\hline hsa05212 & Pancreatic cancer & 2 & 74 & 0.0379 & CDK4, RAC1 \\
\hline hsa04610 & $\begin{array}{l}\text { Complement and } \\
\text { coagulation cascades }\end{array}$ & 2 & 78 & 0.0409 & PLAT, PLAU \\
\hline hsa04146 & Peroxisome & 2 & 81 & 0.0429 & CAT, NOS2 \\
\hline hsa05132 & Salmonella infection & 2 & 84 & 0.045 & NOS2, RAC1 \\
\hline hsa05210 & Colorectal cancer & 2 & 85 & 0.045 & CTNNB1, RAC1 \\
\hline hsa05323 & Rheumatoid arthritis & 2 & 84 & 0.045 & CD86, FLT1 \\
\hline hsa04211 & $\begin{array}{l}\text { Longevity regulating } \\
\text { pathway }\end{array}$ & 2 & 88 & 0.0462 & ADIPOQ, CAT \\
\hline hsa05222 & Small cell lung cancer & 2 & 92 & 0.0492 & CDK4, NOS2 \\
\hline hsa04064 & $\begin{array}{l}\text { NF-kappa B signaling } \\
\text { pathway }\end{array}$ & 2 & 93 & 0.0493 & PLAU, TNFRSF1A \\
\hline
\end{tabular}

\section{Figures}




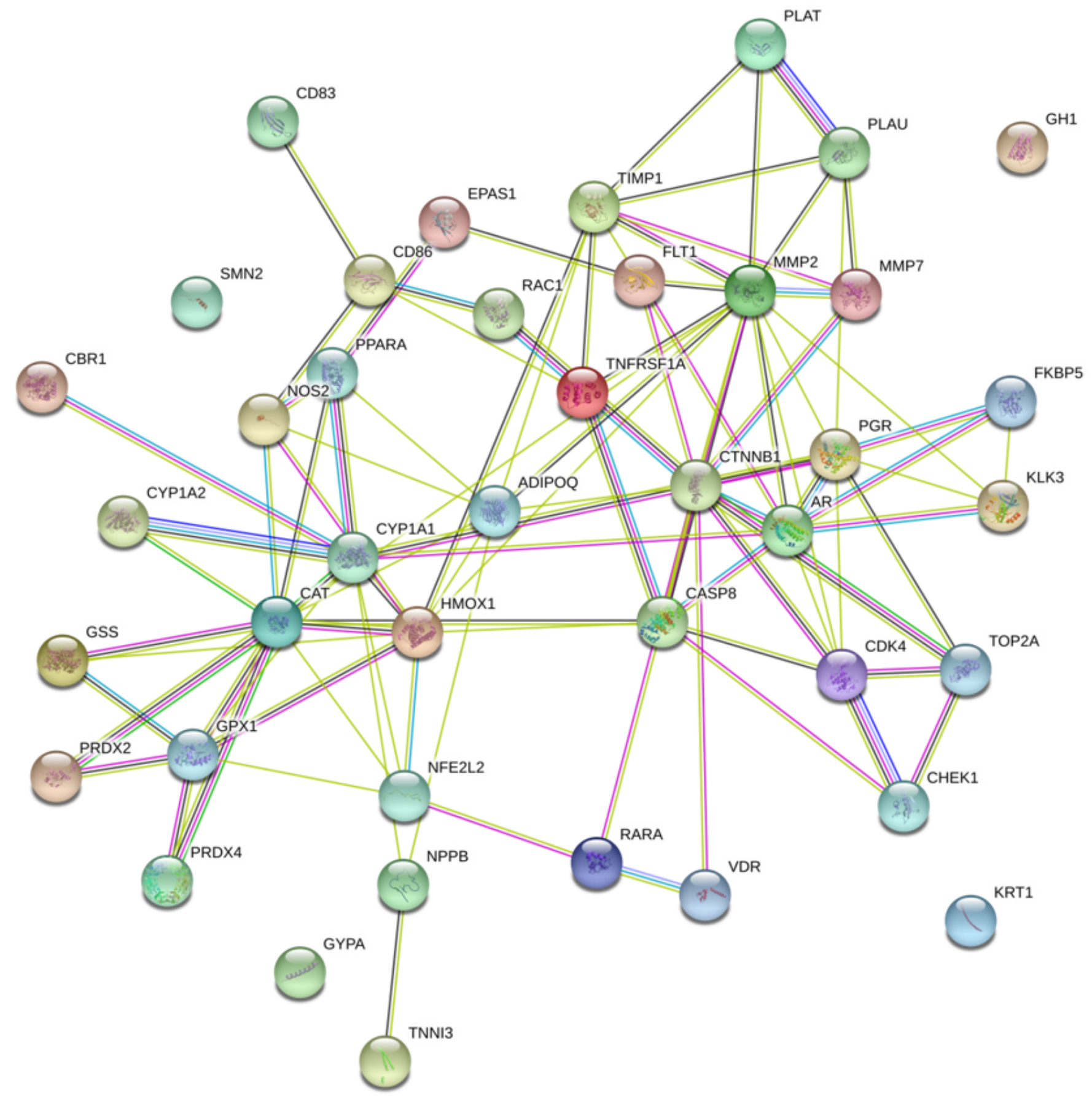

Figure 1

Protein-protein interaction of regulated proteins 


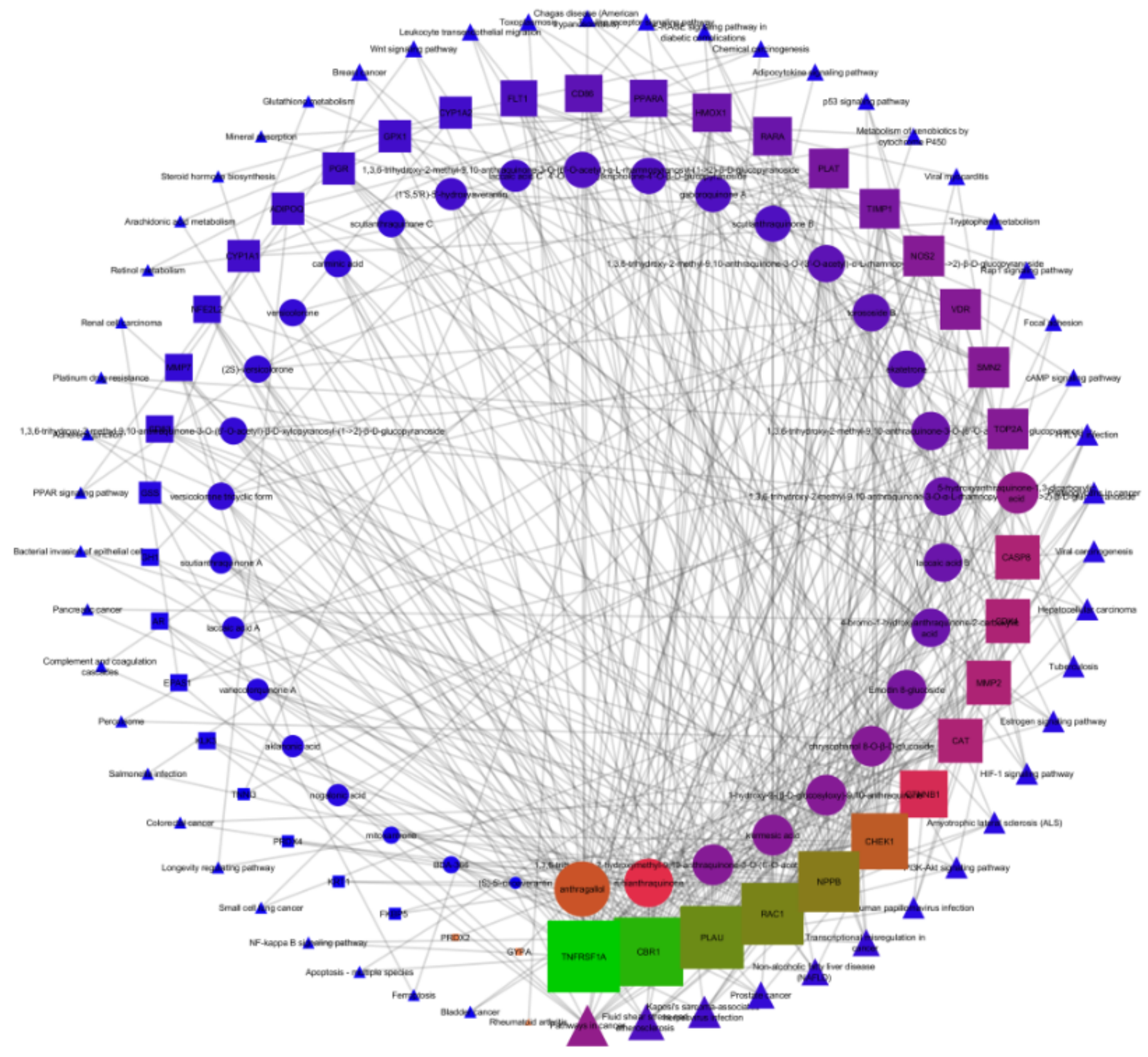

$\begin{array}{llll}\text { Edge Count } & 1 & 39 \\ & & \mathbf{\Delta} \text { pathways } \boldsymbol{\mathbf { a }} \text { targets } \bullet \text { anthraquinones }\end{array}$

Figure 2

Network interaction of anthraquinone derivatives with their proteins and regulated pathways 


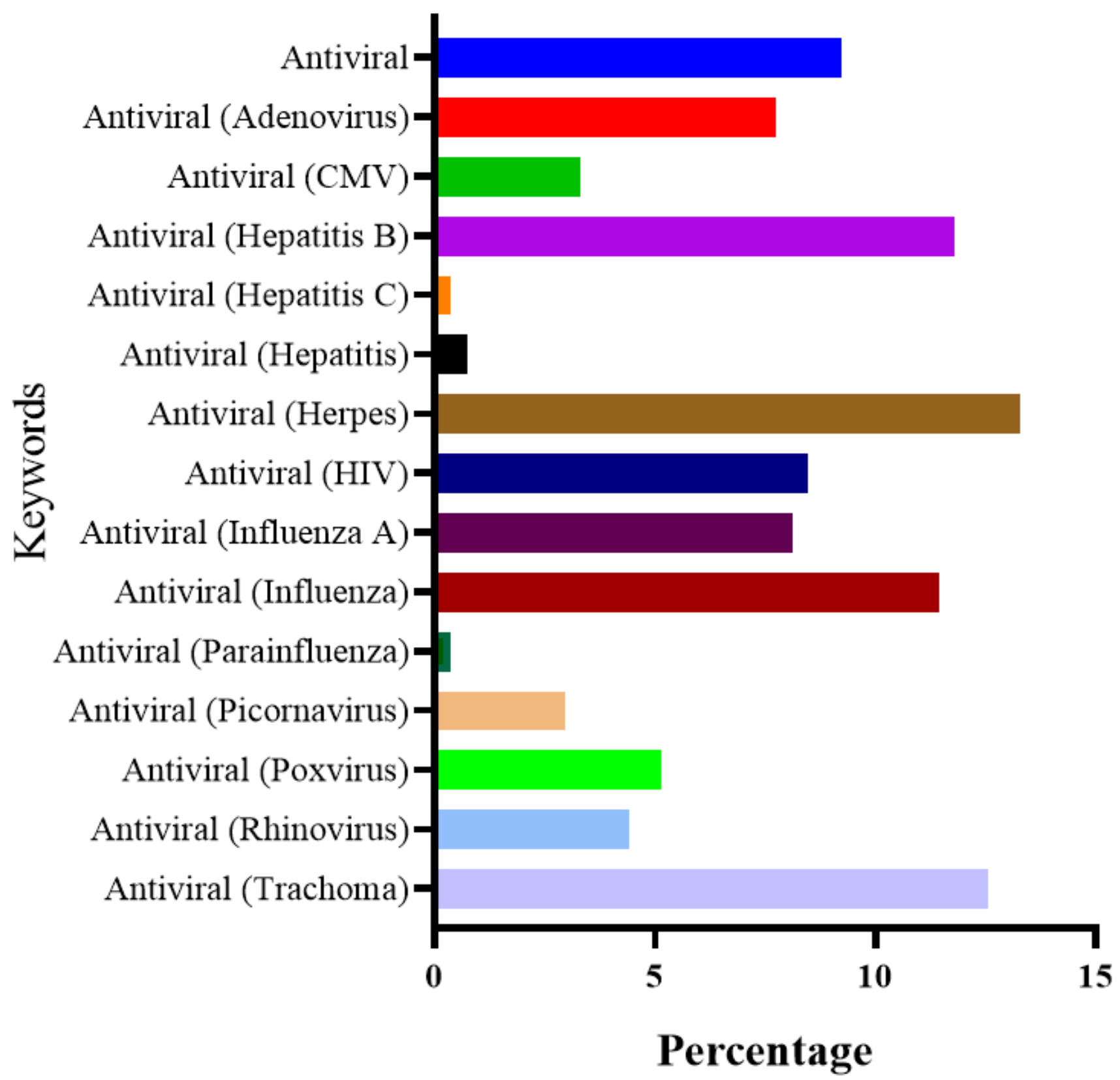

Figure 3

Predicted anti-viral activity of anthraquinone derivatives against multiple viruses 
A

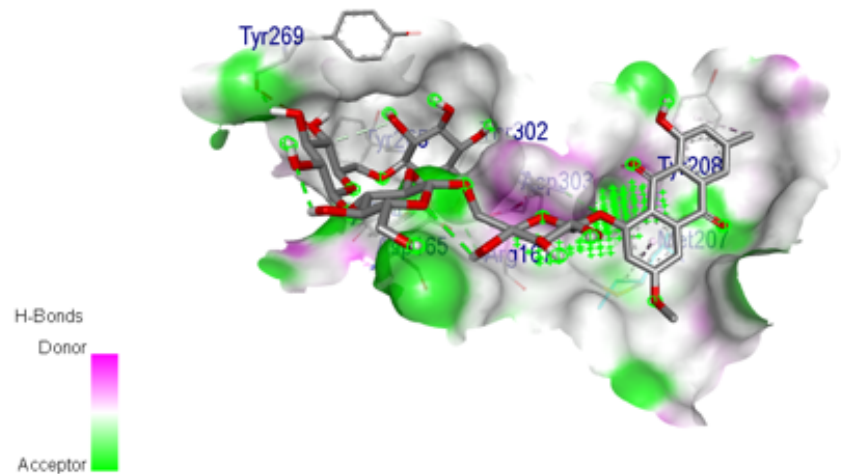

B

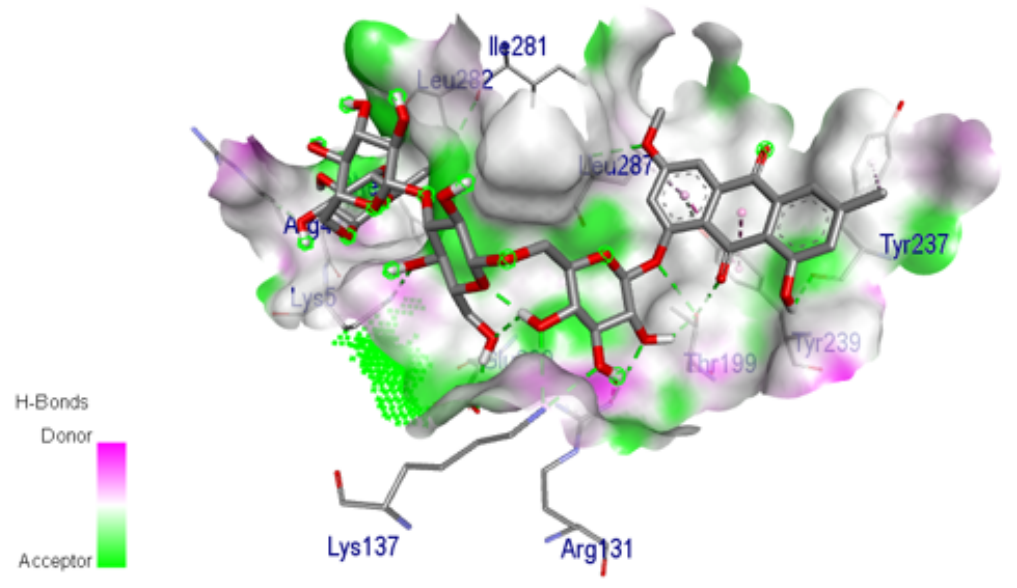

C

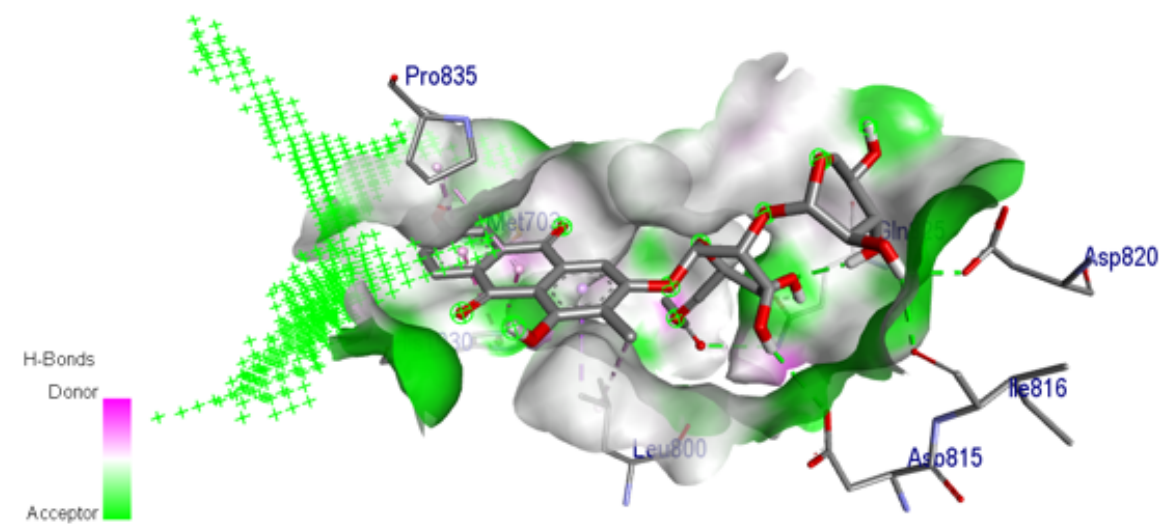

\section{Figure 4}

Interaction of Torososide B with (A) Papain-Like Protease and (B) Coronavirus Main Proteinase and 1,3,6-trihydroxy-2methyl-9,10-anthraquinone-3-0-(6'-0-acetyl)- $\beta$-D-xylopyranosyl-(1->2)- $\beta$-D-glucopyranoside (C) with spike protein

\section{Supplementary Files}

This is a list of supplementary files associated with this preprint. Click to download.

- Tables1S2.xlsx 